\title{
SIGNIFICANCE OF REPORTING CANNON BALLS IN DIAGNOSING BACTERIAL VAGINOSIS INFECTION IN PAP SMEAR
}

\author{
Kricha Pande, ${ }^{1}$ Shraddha Koirala, ${ }^{1}$ and Astha Shrestha ${ }^{2}$
}

\begin{abstract}
Bacterial vaginosis is the most common cause of vaginitis. It is caused by depopulation of lactobacilli from the normal vaginal flora and overgrowth of Gardnerella vaginalis and other anaerobic species. Pap smear being a screening and diagnostic tool for malignancy, is equally important to diagnose infective pathology as well. This study tried to establish the significance of reporting the presence of cannon balls in Pap smears and whether their presence suggested bacterial vaginosis or not. This was a cross sectional study conducted at Nepal Medical College, Teaching Hospital (NMCTH), Kathmandu for duration of one year (January 2020 to December 2020). Pap smears were sent from gynaecology department and standard routine Pap stain was done in Pathology Department. Presence of bacterial vaginosis and cannon balls were noted. Total of 799 Pap smears were received. The mean age of bacterial vaginosis was $38.2 \pm 9.6$ years. The age group of $31-40$ years $(n=32,39 \%)$ was most commonly affected. Bacterial vaginosis was seen in 81 pap smears out of 799 pap smears. The prevalence of bacterial vaginosis was $10.1 \%$. Of the total of 799 cases of Pap smears, cannon balls were seen in $9.1 \%$ cases and among the bacterial vaginosis, cannon balls were seen in $48 \%$ cases.There was significant association between cannonballs and bacterial vaginosis $(\mathrm{p}<0.0001)$. Thus, the present study re-enforces the fact that Pap smear is also very effective tool to diagnose bacterial vaginosis.
\end{abstract}

\section{KEYWORDS}

Bacterial vaginosis, cannon balls, Pap smear

\section{CORRESPONDING AUTHOR}

Dr. Kricha Pande

Assistant Professor

Department of Pathology,

Nepal Medical College Teaching Hospital

Attarkhel, Gokarneshwor-8, Kathmandu, Nepal

Email: krichapande@gmail.com

Orcid No: https://orcid.org/0000-0002-9303-831X

DOI: https://doi.org/10.3126/nmcj.v23i2.38507 


\section{INTRODUCTION}

The Papanicolaou smear (Pap smear), a routine screening test for cancer of the uterine cervix, was first reported in 1928 and its efficacy was proved by 1941. Since then, it has been used worldwide as a clinical tool for the early detection of cancer. ${ }^{1}$ Though Pap smear is a screening tool for neoplastic as well as non neoplastic lesions of female genital tract, it can also be used for detections of micro-organisms.

"The Bethesda system of reporting cervical cytology" reporting system was established in 2001 and was updated in 2014. This system is followed worldwide in order to gain the reproducibility and to have uniformity in reporting. Besides the important role of Pap smear in cancer cytology, this has importance in microbial identification as well. Cervical cytology has relatively high specificity for most of the organisms and reporting them can be helpful in alerting clinicians to a potential new diagnosis. ${ }^{2}$

There are list of organisms which can be identified in routine Pap smears. These include Trichomonas vaginalis, Bacterial vaginosis (BV), Candida albicans, Leptothrix, Actinomyces and viral inclusions as well.

Bacterial vaginosis is the most common cause of vaginitis. BV which is an overgrowth of anaerobic organisms in the vagina, is associated with significant morbidity. ${ }^{3}$ Depopulation of lactobacilli from the normal vaginal flora and overgrowth of Gardnerella vaginalis and other anaerobic species are the presumed etiology. ${ }^{4}$ $\mathrm{BV}$ is characterized microbiologically by replacement of the Lactobacillus-predominant vaginal flora by $G$. vaginalis, Bacteroides species, Mobiluncus species and genital Mycoplasmas. ${ }^{5}$

A variety of cytological changes suggestive of genital tract infection may be noted during microscopy of a Pap smear. ${ }^{6}$ These changes can be a clue to the diagnosis of certain microbial infection. The diagnosis of bacterial vaginosis in Pap smear is given as "Shift in normal vaginal flora suggestive of BV" in accordance to The Bethesda system for reporting cervical cytology 2014. The criteria for this diagnosis is presence of filmy background, presence of clue cells and or cannon balls/polyballs. Presence of clue cells and filmy background favors "Shift in vaginal flora suggestive of BV". Individual squamous cells are covered by a layer of coccobacilli that obscure the cell membrane, forming the socalled clue cells. Filmy background is due to large numbers of coccobacilli. ${ }^{2}$ Cannon balls are neutrophils adherent to epithelial cells, often seen in vaginal Pap smears of patients with trichomoniasis, chlamydiasis and BV.7,8

The identification of neutrophil alone is not sufficient to diagnose the presence of microorganisms in Pap smear. Neutrophil in the Pap smear are a nonspecific finding, particularly if they are low in number or if they are seen in the premenstrual and the menstrual phases. ${ }^{8}$ Hence, this study tried to establish the significance of reporting the presence of cannon balls in Pap smears and whether their presence suggested bacterial vaginosis or not.

\section{MATERIALS AND METHODS}

This was a cross sectional study conducted at Nepal Medical College, Teaching Hospital (NMCTH), Jorpati, Kathmandu for a duration of one year (January 2020 to December 2020). All the patients visiting gynecology OPD (symptomatic/asymptomatic as well as pregnant ladies) who were screened and fit for Pap smear examination were counseled. Pap smears were prepared by gynecologist after proper counseling and after taking verbal consent. These Pap smears were fixed in isopropanolol and sent to the Department of Pathology. These slides were stained using Papanicolaou stain. Conventional method of Pap smear staining using standard method was done.

The stained slides were examined under binocular microscope. "The Bethesda system for reporting of cervical pathology 2014" was followed for reporting. Unsatisfactory specimens were excluded from the study. Besides diagnosing the intraepithelial lesions and carcinoma, presence of clue cells, cannon balls (pus balls/polyballs) and filmy/hazy background were noted. The diagnosis of shift in vaginal flora suggestive of BV was given if there were presence of clue cells (more than $20 \%$ ) and hazy background due to proliferation of coccobacilli. ${ }^{9}$ The coccobacilli were visualized in pap stain as clumps of round coccus organism. Individual squamous cells which are covered by a layer of coccobacilli that obscure the cell membrane, formed the so-called clue cells. ${ }^{10}$ Clue cells are squamous cells having adhered bacteria on their surface (Fig. 1).

Filmy background was due to large numbers of coccobacilli. Predominance of coccobacilli represented a shift in vaginal flora from lactobacilli to a polymicrobial process involving several types of obligate and facultative anaerobic bacteria, including but not limited to G. vaginalis, Peptostreptococcus, Bacteroides, 


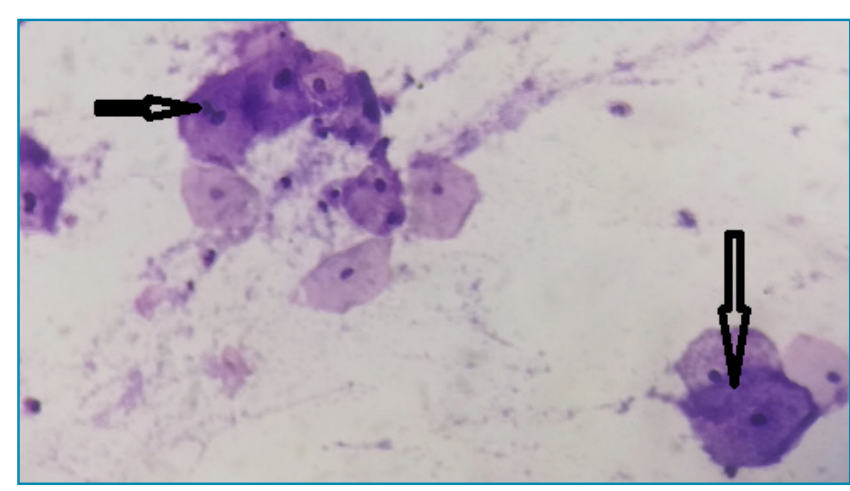

Fig. 1: Clue cells in bacterial vaginosis (Pap stain, 40X).

and Mobiluncus spp. ${ }^{11}$ Once the diagnosis of BV was made on the basis of clue cells and filmy background, it was compared with the presence of cannon balls. The obtained data was entered in Microsoft excel and results were obtained. Ethical clearance was taken from the Institutional Review Committee of NMCTH.

\section{RESULTS}

Total of 799 Pap smears were received during the study period. The age range of bacterial vaginosis varied from 22 to 65 years. The mean age group for BV was $38.2 \pm 9.6$ years. The median age group was 36 years.

Bacterial vaginosis was seen in 81 Pap smears out of 799 Pap smears. The prevalence of BV was $10.1 \%$.

The age group of $31-40$ years $(n=32,39 \%)$ was most commonly affected, followed by 21-30 years $(n=21,26 \%)$. The least affected group was 61-70 years $(n=3,4 \%)$ (Fig. 2 ).

Cannon balls were seen in $73(9.1 \%)$ cases of total 799 Pap smears. 39 (48\%) cases of bacterial vaginosis showed cannon balls (Fig. 3). There is significant association between cannonballs and bacterial vaginosis $(\mathrm{p}<0.0001)$. The significance of presence of cannon balls in BV is shown in table 1.
Besides BV, cannon balls were also seen in other diseases like Trichomniasis and even in cases of heavy dense inflammatory smear. Other associated findings seen in cases of BV were presence of $T$. Vaginalis in 12 cases and reactive cellular atypia in 9 cases and both trichomoniasis and cellular atypia in 1 case out of 81 bacterial vaginosis cases.

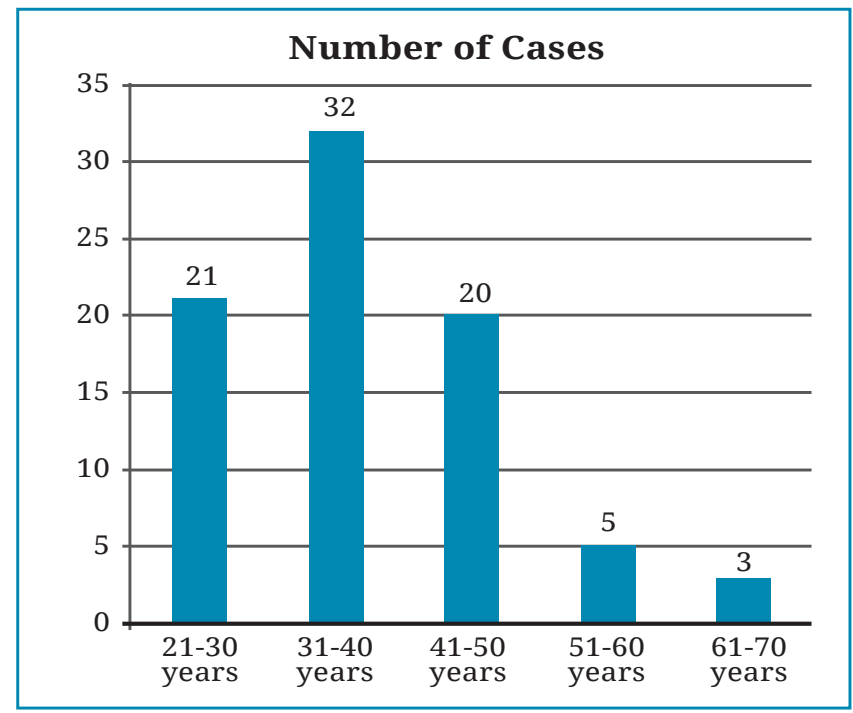

Fig. 2: Age distribution in bacterial vaginosis cases.

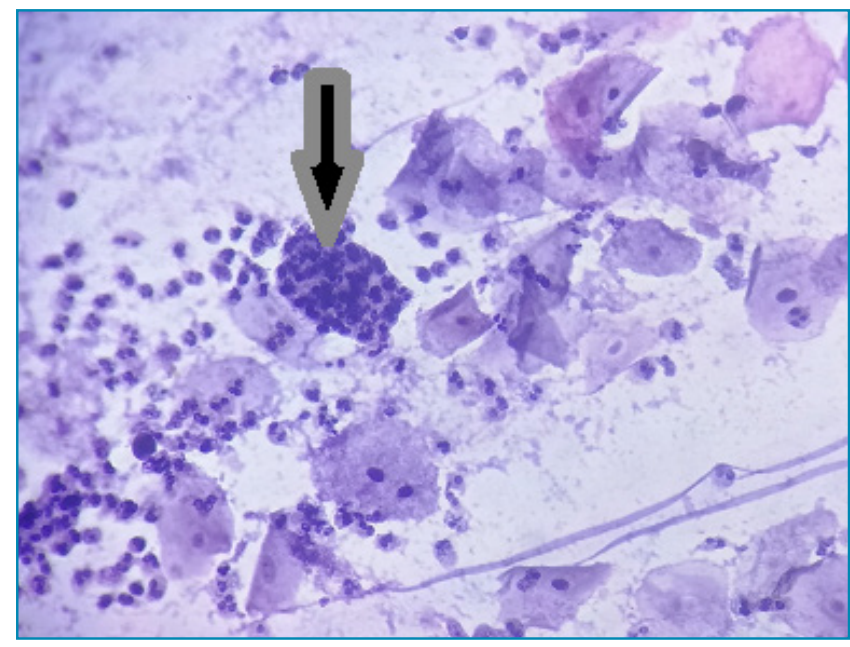

Fig. 3: Cannon balls in Pap smear (Pap stain, 40X).

\section{Table 1: Relation between cannon balls and bacterial vaginosis.}

Cannon balls Yes

Yes

No

Total (n; \%)

\section{Bacterial vaginosis}

No

$34(5 \%)$

$684(95 \%)$

$718(89.9 \%)$ p-value (Sig level <0.05)

$42(52 \%)$

$81(10.1 \%)$

$(78)$ 


\section{DISCUSSION}

Bacterial vaginosis has been known in medicine since ages. In 1980, Greenwood and Pickett renamed G. vaginalis in honor of Gardner who had first reported the association between nonspecific vaginitis and this bacteria.${ }^{12}$ In the same year, the name $G$. vaginalis was also supported by a second taxonomic study conducted by Piot. ${ }^{13}$ Since 1983 physicians have used the term "bacterial vaginosis" to differentiate the vaginal discharge syndrome described by Gardner and Dukes from those caused by other microorganisms (e.g., parasites or fungi). ${ }^{14}$

For clinicians, BV is a common vaginal condition characterized by at least three of the following four Amsel criteria: 1) thin, gray/white discharge; 2) malodorous "fishy" discharge upon adding $10 \%$ potassium hydroxide; 3) high vaginal $\mathrm{pH}(>4.5)$, and 4) identification of vaginal epithelial cells heavily coated with bacteria (i.e., "clue cells"). ${ }^{10}$

Bacterial vaginosis was seen in the age group of 22-65 years. The similar age group was seen in a study done by Eriksson et al. ${ }^{15}$ Their study showed age groups of 35 and 50 years as the most common age group for BV. The mean age group for bacterial vaginosis was $38.2 \pm 9.6$ years in our study. Bukhari et al ${ }^{16}$ also reported similar mean age group in their study.

Bacterial vaginosis was most commonly seen in reproductive age group (31-40 years). The least affected group was peri and post menopausal age group in this study. Similarly, Lakshmi et al ${ }^{17}$ and Barouti et al ${ }^{18}$ also stated that even though BV can occur in any age group, it was more commonly seen in reproductive age group. However, another study by Brooks-Smith-Lowe et $a l^{19}$ stated that BV was more common in early reproductive age group (20-29 years), which was a little younger age group than our study.

Different studies showed different rates of BV infection throughout the world. Murta et $a l^{20}$ stated that the prevalence of BV differs widely from country to country within the same region and even within similar population groups and is estimated to be in the range of $8 \%$ to $75 \%$. The prevalence of BV was $10.1 \%$ in this study. The prevalence of BV in India was shown to be $48 \%$ by Lallar et $a^{21}$, which is quite high in comparison to this study. However, other studies showed almost similar rates of BV infection in females. Brooks-SmithLowe et $a l^{19}$ (19.5\%, Grenada), Barouti et $a l^{18}$ (17, Iran \%), Haltas et al ${ }^{22}$ (7.76\%, Turkey) and Bitew et $a l^{23}$ (48.6\%, Ethiopia) showed different prevalence rate in different parts of the world. Yen et $a l^{24}$ stated that women from Southeast Asia, Australia, New Zealand, and Indonesia have rates of $\mathrm{BV}$ that are typically greater than $30 \%$. The low rate of BV in our study may be the result of small sample size which is due to covid pandemic during the study period. A larger sample size will be better representation of entire population and it is a need in near future to provide the more accurate results.

Cannon balls were seen in $48 \%$ of BV with significant association between cannonballs and bacterial vaginosis $(\mathrm{p}<0.0001)$. Similarly, a significant association was seen in a study done by Murthy et al where cannon balls were found in $84.4 \%$ cases of BV. ${ }^{7}$ Likewise, Karani et $a l^{25}$ stated that Pap smears have moderate sensitivity in diagnosing BV.

Hence, it is concluded that inclusion of BV assessment as a standard component of Pap smears warrants consideration. The present study also re-enforces the fact that Pap smear is an effective tool to diagnose BV apart from its screening property for the intraepithelial lesions.

In conclusion, though, Pap smear is a screening tool for carcinoma of cervix and endometrium, this is an equally efficient method to diagnose infective pathology. $48 \%$ cases of BV showed presence of cannon balls with a statistically significant association ( $<<0.0001)$ in our study. Hence, presence of cannon balls in the Pap smear definitely calls for a search of clue cells to diagnose BV.

\section{ACKNOWLEDGEMENT}

I would like to thank all the colleagues from Department of Pathology as well from the Department of Gynecology and Obstretics for their help during the study period.

\section{Source of Research Fund: None}

Conflict of Interest: None

\section{REFERENCES}

1. Vilos GA. The history of the Papanicolau smear and the odyssey of George and Andromache Papanicolaou. Obstet Gynecol 1998; 91: 479-83.

2. Nayar R, Wilbur DC. The Pap test and Bethesda 2014. Cancer Cytopathol 2015; 123: 271-81.

3. Heller DS, Maslyak S, Skurnick J. Is the presence of Trichomonas on a Pap smear associated with 
an increased incidence of bacterial vaginosis? J Low Genit Tract Dis 2006; 10: 137-9.

4. Wang J. Bacterial vaginosis. Prim Care Update Obs Gynaecol 2000; 7: 181-5.

5. Hillier SL. Diagnostic microbiology of bacterial vaginosis. Am J Obstet Gynecol 1993; 169: 455-9.

6. McMillan A. The detection of tal tract infection by Papanicolaou-stained tests. Cytopathology 2006; 17: 317-22.

7. Krishnamurthy V, Satish S, Vimalambike MG. Cannonballs in Pap smears: Double whammy of bacterial vaginosis and associated Infections. Acta Cytol 2016; 60: 53-7.

8. Bodal VK, Kaur S, Bhagat R, Kaur R, Bal MS."Cannon balls or pus balls" in Pap smears: a case report. J Clin Diagn Res 2013; 7: 1715-6.

9. Discacciati MG, Simoes JA, Amaral RG et al. Presence of $20 \%$ or more clue cells: an accurate criterion for the diagnosis of bacterial vaginosis in Papanicolaou cervical smears. Diagn Cytopathol 2006; 34: 272-6.

10. Amsel R, Totten PA, Spiegel CA, Chen KC, Eschenbach D, Holmes KK. Nonspecific Vaginitis. Diagnostic criteria and microbial and epidemiologic associations. Am J Med 1983; 74: 14-22.

11. Georgijevic A, Cjukic-Ivancevic S, Bujko M. Bacterial vaginosis. Epidemiology and risk factors. Srp Arh Celok Lek 2000; 128: 29-33.

12. Greenwood JR, Pickett MJ. Transfer of Haemophilus vaginalis Gardner and Dukes to a new genus, Gardnerella: G. vaginalis (Gardner and Dukes). Int'l J Syst Bacteriol 1980; 30: 170-8.

13. Piot P, van Dyck E, Goodfellow M, Falkow S. A taxonomic study of Gardnerella vaginalis (Haemophilus vaginalis) Gardner and Dukes 1955. J Gen Appl Microbiol 1980; 119: 373-96.

14. Bautista CT, Wurapa E, Sateren WB, Morris S, Hollingsworth B, Sanchez JL. Bacterial vaginosis: a synthesis of the literature on etiology, prevalence, risk factors, and relationship with chlamydia and gonorrhea infections. Mil Med Res 2016; 3: 4.

15. Eriksson K, Adolfsson A, Forsum U, Larsson PG. The prevalence of BV in the population on the Åland Islands during a 15-year period.
APMIS 2010; 118: 903-8. Doi: 10.1111/j.16000463.2020.02678.x.

16. Bukhari $\mathrm{MH}$, Majeed $\mathrm{M}$, Qamar $\mathrm{S}$ et al. Clinicopathological study of Papanicolaou (Pap) smears for diagnosing of cervical infections. Diagn Cytopathol 2012; 40: 35-41.

17. Lakshmi K, Aishwarya Chitralekha S Jr, Menezes GA. Review on infectious vaginitis. Res J Pharm Biol Chem Sci 2013; 4: 679.

18. Barouti E, Farzaneh F, Sene AA, Tajik $Z$, Jafari $B$. The pathogenic microorganisms in papanicolaou vaginal smears and correlation with inflammation.J Family Reprod Health 2013; 7: 23-7.

19. Brooks-Smith-Lowe K, Rodrigo S. Prevalence of bacterial vaginosis in Grenadian women of reproductive age. West Indian Med J 2013; 62: 599-603.

20. Murta EFC, Silva AO, Silva EAC, Adad SJ. Frequency of infectious agents for vaginitis in non- and hysterectomized women. Arch Gynecol Obst 2005; 273: 152-6.

21. Lallar M, Nanda S, Nandal R. Lower Genital Tract Infections in HIV-Infected Women: Can We Afford to Miss? J Obst Gynaecol India 2015; 65: 45-9.

22. Haltas H, Bayrak R, Yenidunya S.To determine of the prevalence of Bacterial Vaginosis, Candida sp, mixed infections (Bacterial Vaginosis + Candida $\mathrm{sp})$, Trichomonas Vaginalis, Actinomyces sp in Turkish women from Ankara, Turkey. Ginekol Pol 2012; 83: 744-8.

23. Bitew A, Abebaw Y, Bekele D, Mihret A. Prevalence of Bacterial Vaginosis and Associated Risk Factors among Women Complaining of Genital Tract Infection. Int'l J Microbiol 2017; 2017: 4919404.

24. Yen S, Shafer MA, Moncada J, Campbell CJ, Flinn $\mathrm{SD}$, Boyer CB. Bacterial vaginosis in sexually experienced and non-sexually experienced young women entering the military. Obst Gynecol 2003; 102: 927-33.

25. Karani A, De Vuyst H, Luchters S et al. The Pap smear for detection of bacterial vaginosis. Int'l J Gynaecol Obst 2007; 98: 20-3. 